\title{
Effects of temperature on the transmission of Yersinia Pestis by the flea, Xenopsylla Cheopis, in the late phase period
}

\author{
Anna M Schotthoefer ${ }^{1,2^{*}}$, Scott W Bearden ${ }^{1}$, Jennifer L Holmes ${ }^{1}$, Sara M Vetter ${ }^{1,3}$, John A Montenieri ${ }^{1}$, \\ Shanna K Williams ${ }^{1}$, Christine B Graham¹, Michael E Woods ${ }^{1,4}$, Rebecca J Eisen ${ }^{1}$ and Kenneth L Gage ${ }^{1}$
}

\begin{abstract}
Background: Traditionally, efficient flea-borne transmission of Yersinia pestis, the causative agent of plague, was thought to be dependent on a process referred to as blockage in which biofilm-mediated growth of the bacteria physically blocks the flea gut, leading to the regurgitation of contaminated blood into the host. This process was previously shown to be temperature-regulated, with blockage failing at temperatures approaching $30^{\circ} \mathrm{C}$; however, the abilities of fleas to transmit infections at different temperatures had not been adequately assessed. We infected colony-reared fleas of Xenopsylla cheopis with a wild type strain of Y. pestis and maintained them at 10, 23, 27, or $30^{\circ} \mathrm{C}$. Naïve mice were exposed to groups of infected fleas beginning on day 7 post-infection (p.i.), and every 3-4 days thereafter until day 14 p.i. for fleas held at $10^{\circ} \mathrm{C}$, or 28 days p.i. for fleas held at $23-30^{\circ} \mathrm{C}$. Transmission was confirmed using Y. pestis-specific antigen or antibody detection assays on mouse tissues.
\end{abstract}

Results: Although no statistically significant differences in per flea transmission efficiencies were detected between 23 and $30^{\circ} \mathrm{C}$, efficiencies were highest for fleas maintained at $23^{\circ} \mathrm{C}$ and they began to decline at 27 and $30^{\circ} \mathrm{C}$ by day 21 p.i. These declines coincided with declining median bacterial loads in fleas at 27 and $30^{\circ} \mathrm{C}$. Survival and feeding rates of fleas also varied by temperature to suggest fleas at 27 and $30^{\circ} \mathrm{C}$ would be less likely to sustain transmission than fleas maintained at $23^{\circ} \mathrm{C}$. Fleas held at $10^{\circ} \mathrm{C}$ transmitted $Y$. pestis infections, although flea survival was significantly reduced compared to that of uninfected fleas at this temperature. Median bacterial loads were significantly higher at $10^{\circ} \mathrm{C}$ than at the other temperatures.

Conclusions: Our results suggest that temperature does not significantly effect the per flea efficiency of $Y$. pestis transmission by $X$. cheopis, but that temperature is likely to influence the dynamics of $Y$. pestis flea-borne transmission, perhaps by affecting persistence of the bacteria in the flea gut or by influencing flea survival. Whether $Y$. pestis biofilm production is important for transmission at different temperatures remains unresolved, although our results support the hypothesis that blockage is not necessary for efficient transmission.

Keywords: Yersinia pestis, Xenopsylla cheopis, biofilm, flea-borne transmission, temperature

\section{Background}

It is well documented that temperature is an important regulator of the transmission dynamics of vector-borne pathogens. This relationship is largely related to the effects that temperature has on the survival, growth, development, and reproduction of pathogens and their

\footnotetext{
* Correspondence: Schotthoefer.Anna@mcrf.mfldclin.edu

${ }^{1}$ Bacterial Diseases Branch, Division of Vector Borne Diseases, National Center for Emerging and Zoonotic, Infectious Diseases, Centers for Disease Control and Prevention, Fort Collins, CO 80521, USA

Full list of author information is available at the end of the article
}

vectors $[1,2]$. Temperature also has the ability to alter the behavior and activity of vectors, resulting in changes in contact rates between vectors, pathogens, and the hosts that may be involved in pathogen life cycles [3]. Changes in temperatures, therefore, have the potential to shift or expand vector-host-pathogen geographic ranges, modify the seasonality or phenology of infections, and lead to changes in pathogen generation times and transmission rates, thereby altering the burden of disease on a host population. These potential changes 
are of particular concern with regard to the predictions of climate change and its effects on vector-borne diseases $[4,5]$.

Yersinia pestis, the causative agent of plague, is a Gram-negative bacterium that infects primarily rodents, but which may also infect a wide array of other mammalian hosts, including humans. Fleas are employed by the pathogen as vectors, and the majority of transmission events are believed to occur through flea bites [6]. Thus, the success of the bacterium depends, in part, on its ability to adapt and quickly respond to the disparate temperature environments encountered in the mammalian and flea hosts [7]. Success within the flea, specifically, appears to be linked to the ability of $Y$. pestis to rapidly form a biofilm that is based on the synthesis of an extracellular polysaccharide matrix once inside the flea gut lumen [8]. The production of a biofilm creates large aggregates of $Y$. pestis, which presumably are not easily removed from the flea's gut via defecation, and attachment and growth of the biofilm on the surfaces of the proventriculus, a valve that connects the esophagus to the midgut, act to plug the gut lumen, in a condition referred to as blockage. Blockage impedes the ability of the flea to ingest subsequent blood meals, forcing any blood taken up to be regurgitated back into the host. It is believed that this action associated with attempted feedings causes some of the bacteria to be dislodged from the biofilm and injected into the host with the blood [8-10]. Transmission by blocked fleas is the mechanism most frequently recognized as an integral, and possibly essential, component of efficient flea-borne transmission [8].

Evidence suggests that the blockage mechanism of flea transmission is mediated by temperature. The ability of the bacteria to colonize the proventriculus and cause blockage in the flea is dependent on the hemin storage locus $(h m s)$ gene complex $[11,12]$, and appears to be optimized around $20-26^{\circ} \mathrm{C}$ [10], the temperature range that would be typical of the flea gut environment in the nests and burrows of rodents in many situations $[13,14]$. As temperature increases from $26^{\circ} \mathrm{C}$, the ability for $Y$. pestis to cause blockage declines and fails and $30^{\circ} \mathrm{C}$ [15], and $\mathrm{hms}$ proteins are degraded circa $37^{\circ} \mathrm{C}$, the body temperature of the mammalian host $[10,16]$. Such observations suggest that biofilm production and flea-borne transmission of $Y$. pestis will decline with rising environmental temperatures, and previous investigations have, in part, supported these predictions. Kartman and Prince [17] reported that fleas held at $20^{\circ} \mathrm{C}$ had the potential to transmit an average of 1.75 new infections to naïve mice, in contrast to fleas held at $30^{\circ} \mathrm{C}$, which only infected on average 0.56 mice. Kartman [18] also observed a more rapid loss of $Y$. pestis infections in fleas held at $29.5^{\circ} \mathrm{C}$ compared to fleas at $23.5^{\circ} \mathrm{C}$.
The effect of temperature on the transmission potential of fleas has been used to explain the variation in seasonal and regional patterns of plague outbreaks. In particular, the dynamics of $Y$. pestis outbreaks in endemic areas typically show a seasonal pattern, with trends of increasing cases being reported as conditions become warmer and more humid, followed by sharp declines in cases once temperatures exceed about $27.5^{\circ} \mathrm{C}$ and humidity decreases [19-23]. Thus, the declines in cases during seasonal periods of hot weather may be attributed to the poorer flea transmission efficiency associated with reduced $h m s$-mediated biofilm production and flea blockage at high temperatures $[10,15,24]$. However, a recent examination of the effects of temperature on the transmission efficiency of fleas during the early-phase period between 1-4 days post-infection (p.i.), sensu [25], found that Xenopsylla cheopis, the Oriental rat flea, held at $30^{\circ} \mathrm{C}$ transmitted $Y$. pestis just as efficiently to naïve mice as fleas held at $23^{\circ} \mathrm{C}$ [26]. Nonetheless, those results do not rule out the possibility that the negative effects of high temperatures predicted for flea transmission efficiency occur during the post-early phase period, when biofilm production and blockage formation is expected to be important (e.g., 12-18 days p.i., [20,27-29]). The primary aim of the current study, therefore, was to explore the effects of warming temperatures on the transmission of $Y$. pestis by $X$. cheopis fleas in the post-early-phase period (referred to here as late phase), between days 7 and 28 p.i. We also continued to examine the effect of a cold temperature $\left(10^{\circ} \mathrm{C}\right)$ on flea transmission to determine if the absence of transmission observed during the early-phase period by Schotthoefer et al. [26] was an indication of a loss of vector competence by $X$. cheopis fleas at this low temperature or a delay in acquiring competence.

\section{Results}

\section{Effects of temperature on flea transmission efficiencies}

None of the fleas maintained at our three high temperatures $\left(23,27\right.$ and $30^{\circ} \mathrm{C}$ ) and used in our challenges transmitted infections on day 7 p.i.; however, after this time point, fleas at these temperatures were able to transmit infections through to days 21 or 28 p.i. (Table 1). Our observed per flea transmission efficiencies were highest at $23^{\circ} \mathrm{C}$. At this temperature, fleas consistently transmitted at per flea efficiencies greater than $12 \%$ until day 28 p.i., when the efficiency dropped to about $4 \%$ (Table 1). In comparison, transmission efficiencies were low for fleas maintained at $27^{\circ} \mathrm{C}$ until they rose to 15.4 and $13.5 \%$ on days 17 and 21 days p.i., respectively. The per flea transmission efficiencies observed at $30^{\circ} \mathrm{C}$ were highest on day 10 p.i. and gradually declined thereafter (Table 1). Despite the trend that per flea efficiencies were higher at 23 than at 27 and $30^{\circ} \mathrm{C}$, the 
Table 1 Transmission efficiencies of infected fleas held at different experimental temperatures during the late phase period

\begin{tabular}{|c|c|c|c|c|c|}
\hline $\begin{array}{l}\text { Temp } \\
\left({ }^{\circ} \mathrm{C}\right)\end{array}$ & $\begin{array}{l}\text { Days } \\
\text { p.i. }\end{array}$ & $\begin{array}{l}\text { Flea infection } \\
\text { prevalence (\%) }\end{array}$ & $\begin{array}{l}\text { Average no. fed, infected fleas per mouse } \\
\text { (total in treatment group) }\end{array}$ & $\begin{array}{l}\text { No. of mice infected } \\
\text { (exposed) }\end{array}$ & $\begin{array}{c}\text { Percent per flea transmission } \\
\text { efficiency }(95 \% \mathrm{Cl})\end{array}$ \\
\hline \multirow[t]{3}{*}{10} & 7 & 100 & $5.0(35)$ & $3(7)$ & $9.81(2.74,25.74)$ \\
\hline & 10 & 97.1 & $5.8(35)$ & $1(6)$ & $2.75(0.17,12.75)$ \\
\hline & 14 & 75.9 & $6.8(54)$ & $3(8)$ & $6.31(1.75,16.31)$ \\
\hline \multirow[t]{6}{*}{23} & 7 & 88.6 & $6.3(44)$ & $0(7)$ & $0(0,6.60)$ \\
\hline & 10 & 95.2 & $6.0(42)$ & $4(7)$ & $12.48(4.33,30.48)$ \\
\hline & 14 & 92.3 & $5.6(39)$ & $4(7)$ & $14.11(4.73,34.11)$ \\
\hline & 17 & 100 & $4.3(30)$ & $4(7)$ & $17.42(6.04,37.42)$ \\
\hline & 21 & 94.1 & 4.9 (34) & $5(7)$ & $21.77(8.67,48.81)$ \\
\hline & 28 & 79.2 & $4.0(24)$ & $1(6)$ & $4.27(0.25,20.27)$ \\
\hline \multirow[t]{6}{*}{27} & 7 & 98.1 & $6.5(52)$ & $0(8)$ & $0(0,5.80)$ \\
\hline & 10 & 96.9 & $4.6(32)$ & $2(7)$ & $7.04(1.30,23.02)$ \\
\hline & 14 & 92.3 & $5.6(39)$ & $1(7)$ & $2.52(0.15,11.93)$ \\
\hline & 17 & 85.7 & $4.0(28)$ & $3(7)$ & $15.41(4.03,44.01)$ \\
\hline & 21 & 83.8 & $5.3(37)$ & $4(7)$ & $13.50(4.75,31.81)$ \\
\hline & 28 & 61.9 & $5.3(21)$ & $0(4)$ & $0(0,11.67)$ \\
\hline \multirow[t]{6}{*}{30} & 7 & 95.0 & $5.6(39)$ & $0(7)$ & $0(0,7.46)$ \\
\hline & 10 & 100 & $5.3(37)$ & $3(7)$ & $9.47(2.64,25.19)$ \\
\hline & 14 & 95.4 & $6.1(43)$ & $3(7)$ & $8.30(2.32,22.62)$ \\
\hline & 17 & 100 & $4.1(29)$ & $2(7)$ & $7.67(1.42,24.58)$ \\
\hline & 21 & 93.3 & $5.0(30)$ & $0(6)$ & $0(0,9.03)$ \\
\hline & 28 & 91.2 & $6.8(34)$ & $1(5)$ & $2.72(0.18,12.69)$ \\
\hline
\end{tabular}

likelihood of a mouse becoming infected was not significantly associated with the temperature at which fleas were held $\left(\chi^{2}=2.9, \mathrm{df}=3, \mathrm{p}=0.41\right)$.

\section{Effects of temperature on Y. pestis infections in fleas}

Infection prevalences, bacterial loads, and flea feeding rates did not differ between male and female fleas maintained at different temperatures (data not shown); therefore, we did not consider this factor in our analyses. Prevalence of infection was influenced by temperature $\left(\chi^{2}=6.8, \mathrm{df}=2, \mathrm{p}=0.034\right)$ and time point $\left(\chi^{2}=24.0\right.$, $\mathrm{df}=5, \mathrm{p}=0.0002)$. Overall prevalences for 23, 27, and $30^{\circ} \mathrm{C}$ fleas were $91.9,89.0$, and $95.8 \%$, respectively. Declining trends in prevalences were observed over time at 23 and $27^{\circ} \mathrm{C}$; however, a significant decline over time was observed only at $27^{\circ} \mathrm{C}\left(\chi^{2}=23.9\right.$, df $=5, \mathrm{p}=$ $0.0002)$. Bacterial loads tended to be higher in fleas held at $23^{\circ} \mathrm{C}$ than in fleas held at 27 and $30^{\circ} \mathrm{C}$ (Figure 1), although this association was not statistically significant $\left(\chi^{2}=5.6, \mathrm{df}=2, \mathrm{p}=0.061\right)$. Bacterial loads were related to time point $\left(\chi^{2}=22.8, \mathrm{df}=5, \mathrm{p}=0.0004\right)$ and were observed to decline over time in fleas held at 27 and $30^{\circ}$ C (Figure 1).

Although the proportions of fleas that successfully took blood meals when exposed to mice in challenge feeds did not vary significantly across temperatures $\left(\chi^{2}\right.$ $=0.5, \mathrm{df}=2, \mathrm{p}=0.78)$, they were significantly different across time points at $23^{\circ} \mathrm{C}\left(\chi^{2}=12.0, \mathrm{df}=5, \mathrm{p}=0.035\right)$ and $27^{\circ} \mathrm{C}\left(\chi^{2}=11.6, \mathrm{df}=5, \mathrm{p}=0.040\right)$, but not at $30^{\circ} \mathrm{C}$ $\left(\chi^{2}=10.5, \mathrm{df}=5, \mathrm{p}=0.063\right)$. Feeding rates declined with time at 23 and $27^{\circ} \mathrm{C}$ with overall feeding rates averaging $64.8 \%$ on day 7 p.i. and $46.9 \%$ on day 28 p.i. for these temperatures. Fleas maintained at $30^{\circ} \mathrm{C}$, had average feeding rates of $55.7 \%$ on day 7 p.i. and $68.0 \%$ on day 28 p.i.

\section{Effects of temperature on flea survival}

The proportions of fleas surviving between time points was significantly lower at $27^{\circ} \mathrm{C}$ compared to $23^{\circ} \mathrm{C}(\mathrm{t}$ value $=-2.1, \mathrm{df}=1, \mathrm{p}=0.034$ ) (Figure $2 \mathrm{~A}$ ) and lower on days 14,21 , and 24 p.i. than on day 3 p.i. (all p $\leq$ 0.036). On day 3 p.i., $84.0 \%$ of the fleas maintained at $23^{\circ} \mathrm{C}$ had survived since obtaining the infectious blood meal on day 0 , whereas only 78.7 and $79.4 \%$ of the fleas at 27 and $30^{\circ} \mathrm{C}$, respectively, had survived. Survival between days 17 and 21 p.i., had declined to 71.2, 67.2, and $68.0 \%$ for 23,27 , and $30^{\circ} \mathrm{C}$, respectively.

\section{Predictors of $\mathrm{Y}$. pestis transmission}

A stepwise logistic regression analysis incorporating all temperature and time point data identified time point $\left(\chi^{2}=12.8, \mathrm{df}=5, \mathrm{p}=0.026\right)$ and feeding by at least one flea that harbored at least $10^{6}$ bacteria $\left(\chi^{2}=4.01\right.$, $\mathrm{df}=$ $1, \mathrm{p}=0.045)$ as predictive of $Y$. pestis transmission to 


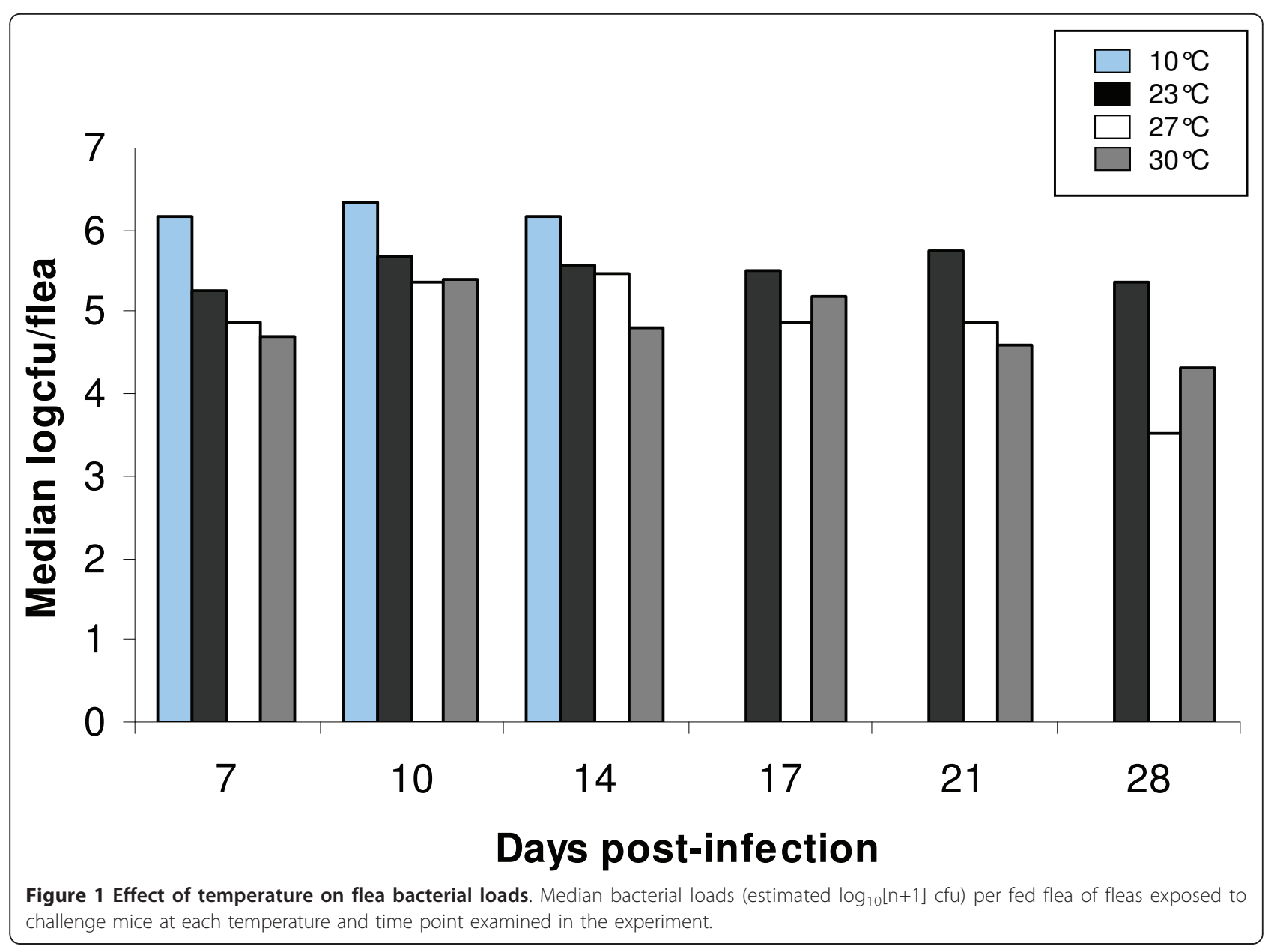

naïve mice. Transmission to mice on day 7 p.i. had a lower probability, whereas the probabilities of transmission on days 17 and 21 p.i were elevated. Mice that were fed on by at least one flea with $10^{6}$ bacteria were 2.33 (95\% CI: 1.019 - 5.33) times more likely to become infected than mice not fed on by such fleas.

\section{Transmission of $\mathrm{Y}$. pestis by fleas held at $10^{\circ} \mathrm{C}$}

Fleas maintained at $10^{\circ} \mathrm{C}$, were able to transmit $Y$. pestis to naïve mice on all the days examined in our current study. The per flea transmission efficiencies observed at this temperature were comparable to those observed for 27 and $30^{\circ} \mathrm{C}$ during the late phase period (Table 1). The bacterial loads in these fleas were maintained on average at a log higher concentration than in the fleas at the three higher temperatures (Figure 1). However, prevalence of infection in the fleas held at $10^{\circ} \mathrm{C}$ dropped from $100 \%$ on day 7 p.i. to $75.9 \%$ on day 14 p.i. Feeding rates were not significantly different across time points for the $10^{\circ} \mathrm{C}$ fleas $\left(\chi^{2}=4.7, \mathrm{df}=2, \mathrm{p}=0.093\right)$. The proportions of fleas surviving between time periods were significantly lower at $10^{\circ} \mathrm{C}$ compared to the fleas at higher temperatures $\left(\chi^{2}=459.2, \mathrm{df}=3, \mathrm{p}<0.0001\right.$; Figure 2A). In examining the effect of $Y$. pestis infection on flea survival in a separate experiment, we determined that the poor survival was probably due to infection and not simply the cold temperature; fleas infected with $Y$. pestis had higher mortality rates than uninfected fleas at $10^{\circ} \mathrm{C}$ ( $\mathrm{t}$ value $=3.4, \mathrm{df}=1, \mathrm{p}=0.042)$, (Figure 2B). Specifically, infected fleas at days 7,10 , and 14 p.i. were less likely to survive between time periods than uninfected fleas (all ps $<0.0001$ ).

\section{Discussion}

Effects of high temperatures on $\mathrm{Y}$. pestis transmission

Temperature has long been associated with human and animal plague outbreaks $[4,20,30]$. Most seasonal outbreaks occur when temperatures range between 24 and $27^{\circ} \mathrm{C}$, and declines in the numbers of cases have generally been reported when temperatures exceed a threshold temperature around $27.5^{\circ} \mathrm{C}[20-23,31]$. A poor ability of fleas to become blocked, and therefore, transmit infections at high temperatures has been hypothesized as an explanation for these declines $[10,15,18,24]$. 


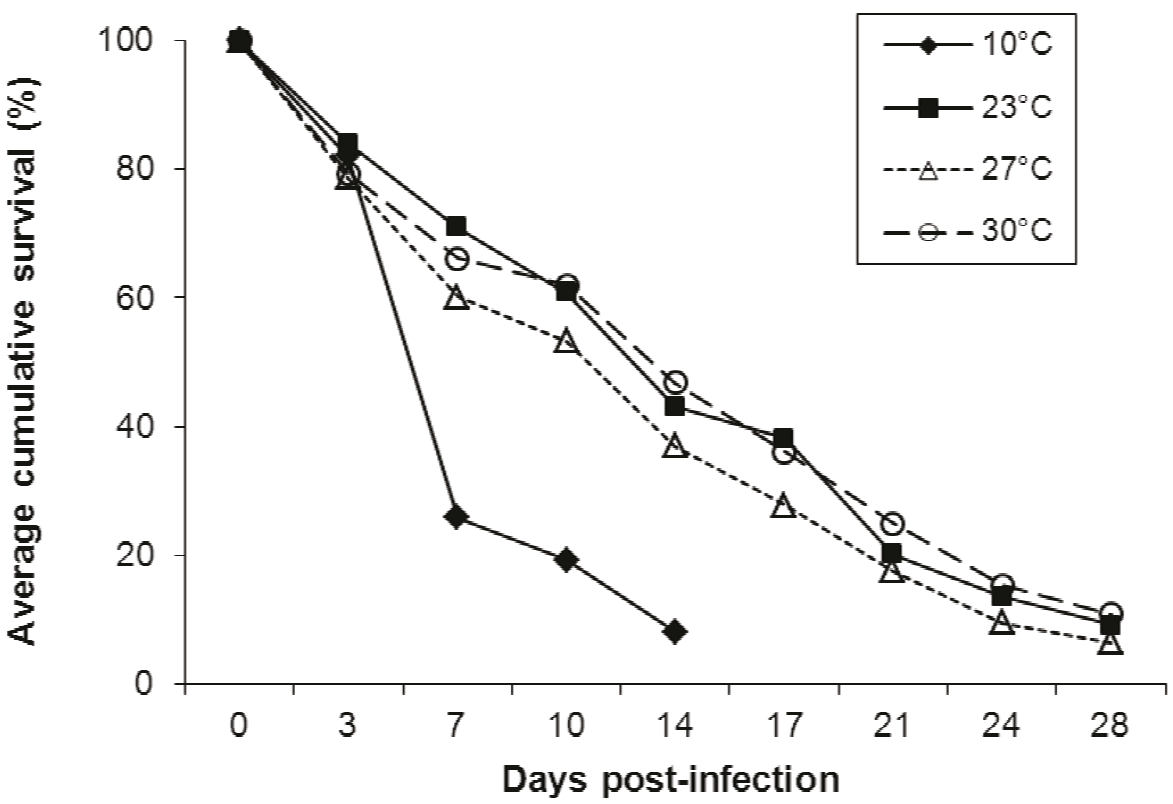

B

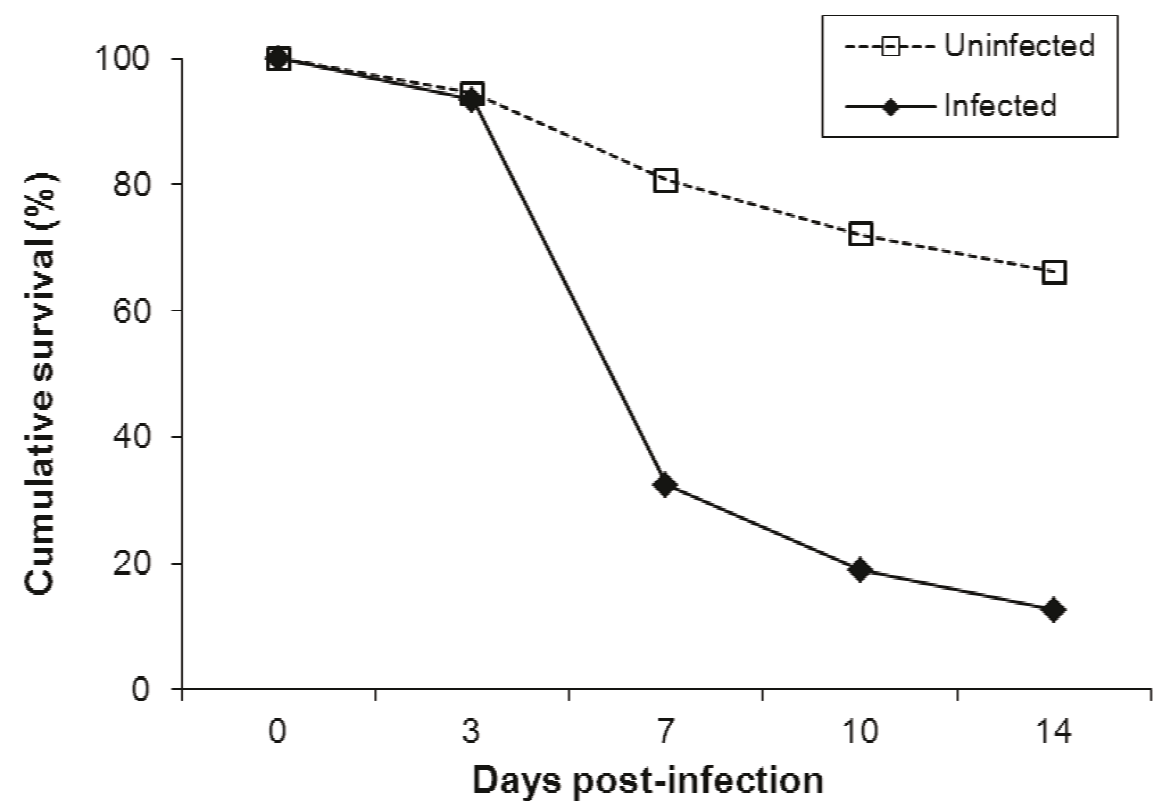

Figure 2 Effect of temperature on flea survival. A) Cumulative survival of infected fleas maintained at each temperature during the late phase infection period. Averages were calculated for the flea cohorts used in 12 artificial feeding trials. B) Cumulative survival of fleas used in a separate experiment to examine the effects of $Y$. pestis infection at $10^{\circ} \mathrm{C}$.

The results from our experimental study partially contradict these predictions because the differences in per flea transmission efficiencies were not statistically significant between 23 and $30^{\circ} \mathrm{C}$. In fact, fleas held at 27 and $30^{\circ} \mathrm{C}$ were reliable transmitters of $Y$. pestis out to at least day 17 p.i., and were still capable of transmitting $Y$. pestis at 21 and 28 days p.i., respectively, even in the absence of blockage. However, we did observe lower transmission efficiencies and flea survival and bacterial loads that declined with time in fleas maintained at 27 and $30^{\circ} \mathrm{C}$, suggesting that plague outbreaks would be terminated or at least be of shorter duration at temperatures of 27 and $30^{\circ} \mathrm{C}$, as predicted. This was in contrast to fleas held at $23^{\circ} \mathrm{C}$ which were able to maintain high average per flea transmission efficiencies through day 21 p.i. 
The ability for the $23^{\circ} \mathrm{C}$ fleas to sustain high transmission efficiencies may have been related to their ability to maintain high bacterial loads throughout the late phase period. We found that $Y$. pestis transmission was positively associated with mice that were fed on by at least one flea with a bacterial load of at least $10^{6}$, and fleas held at $23^{\circ} \mathrm{C}$ were generally able to retain such high loads longer than fleas held at 27 and $30^{\circ} \mathrm{C}$ (Figure 1). The ability of $X$. cheopis to maintain high bacterial loads for long periods of time has been previously observed, and has been suggested as a factor contributing to its success as a vector of $Y$. pestis, possibly because fleas with higher bacterial loads are more likely to become blocked [27,32-34]. It should be noted, however, that the early-phase experiments conducted to date have failed to demonstrate a relationship between bacterial load and transmission success [25,26,35-37]. Even in the present study, although mice that became infected were on average fed on by fleas with higher bacterial loads than mice that did not become infected, a flea group with a summed bacterial load as low as $10^{4.64}$ was able to transmit an infection, and 13 of our 44 (29.5\%) transmission events occurred by flea groups that did not include a flea harboring at least $10^{6}$ bacteria. Moreover, 50 of the $81(61.7 \%)$ flea groups that did contain at least one flea with greater than $10^{6}$ bacteria failed to transmit $Y$. pestis. Therefore, although mice that became infected were likely to have been fed on by fleas with high bacterial loads, a high flea bacterial load alone was not sufficient for transmission.

The location of bacteria in the flea gut is another factor that may help explain the differences observed in the transmission efficiencies between $23^{\circ} \mathrm{C}$ and the two higher temperatures. Colonization of the proventriculus by $Y$. pestis and the subsequent production of biofilm by this bacterium have often been cited as necessary for efficient plague transmission because these steps are thought to be prerequisites for blockage $[9,27,38]$. $Y$. pestis is known to readily colonize the proventriculus and cause blockage in $X$. cheopis at temperatures around $23^{\circ} \mathrm{C}[15,27]$. The ability to cause blockage, however, is lost as temperatures approach $30^{\circ} \mathrm{C}[15,18]$. It is not clear if the ability for $Y$. pestis to colonize the proventriculus also wanes at $30^{\circ} \mathrm{C}$ [but see 18], although fleas at $30^{\circ} \mathrm{C}$ are able to maintain large bacterial masses in their midguts [15]. In addition, temperature-mediated regulation of the hms genes, which are required for blockage [38], occurs at the posttranscriptional level, with $Y$. pestis colonies displaying some ability to store hemin, the phenotype often used to assess hms activity in vitro, at temperatures as high as $35^{\circ} \mathrm{C}$ [16]. Therefore, it is quite likely that $h m s$-mediated biofilm production was not completely inactivated in our study, possibly explaining the ability of fleas held at 27 and $30^{\circ} \mathrm{C}$ to transmit infections, although the higher transmission efficiencies observed at $23^{\circ} \mathrm{C}$ may have been related to more bacteria becoming established in the proventriculus than at 27 and $30^{\circ} \mathrm{C}$. Future studies should examine whether $Y$. pestis growth occurs in the proventriculus and midgut at $23^{\circ} \mathrm{C}$, but primarily occurs only in the midgut in fleas at $30^{\circ} \mathrm{C}$, and if colonization of the proventriculus, but not necessarily blockage, of the flea gut is associated with transmission. Moreover, the role of hms-mediated biofilm production in transmission at different temperatures remains unresolved.

It is unclear what would explain the lack of transmission by fleas held at 23,27 , or $30^{\circ} \mathrm{C}$ on day 7 p.i., given that fleas at these temperatures transmitted $Y$. pestis to naïve mice during the early-phase period of infection (14 days, p.i.) [26], as well as on later days p.i. in this study, but the observation may also relate to the pattern of growth of $Y$. pestis in the flea gut. Although bacterial masses may begin to form in the proventriculus and esophagus of a flea within the first few days of infection $[39,40]$, complete blockage is not typically observed in $X$. cheopis until 12-18 days p.i. [20,27,29,41]. Day 7 p.i. represents a time point between early-phase and later periods when bacterial masses may be forming in the flea gut, but have not yet reached sufficient mass to disrupt passage of blood to the midgut. Of note, also is the observation that in our experiment, day 7 p.i. fleas represented the first cohort of fleas used in challenge feeds after having their first non-infectious maintenance blood meal on day 3 p.i. It may be that ingestion of a non-infectious blood meal during the period when bacterial masses were just beginning to form (e.g., on day 3 p.i.) acted to flush some of the bacteria from the flea gut or displaced them further back in the midgut, such that bacteria were not as readily regurgitated into mice while they fed on day 7 p.i. Over time, although the total population density of bacteria residing in the flea may be lower, the bacterial masses associated with developing $Y$. pestis colonies and the biofilm they produce may become more persistent and available for transmission during subsequent flea feeding events.

\section{Effects of $10^{\circ} \mathrm{C}$ on $\mathrm{Y}$. pestis transmission}

Although we reported in an earlier study that $X$. cheopis fleas maintained at $10^{\circ} \mathrm{C}$ were unable to transmit $Y$. pestis infections to mice during the early-phase period [26], fleas maintained at this temperature were able to transmit $Y$. pestis in the late phase period in our present study, which is consistent with reports by Kartman and Prince [17]. However, our collective observations suggest that $Y$. pestis may behave differently in fleas held under cold environmental conditions. In addition to a delay in the ability to transmit $Y$. pestis, bacterial loads were consistently higher in fleas maintained at $10^{\circ} \mathrm{C}$ compared to 
those held at the three warmer temperatures, and these heavy infections at $10^{\circ} \mathrm{C}$ clearly had a detrimental effect on flea survival, with only about $10 \%$ of infected fleas surviving to day 14 p.i. versus about $67 \%$ of uninfected fleas. Of interest, also is the observation that both the first transmission event and high flea mortality occurred only after fleas were offered their first maintenance feed on day 3 p.i., suggesting that transmission and mortality were dependent upon obtaining another blood meal following infection.

The differences observed at $10^{\circ} \mathrm{C}$ may relate to differences in the expression of $Y$. pestis genes at cold versus warm temperatures [42], and to changes in lipopolysaccharide (LPS) structure that occur at cold temperatures [42-45]. For instance, it is possible that the upregulation of $h m s$ and the yersina murine toxin $(y m t)$ gene, which is necessary for $Y$. pestis survival in the flea gut, allows for the extensive bacterial growth observed in the flea at $10^{\circ} \mathrm{C}$ [42]. It is also possible that the LPS and extracellular matrix that forms at low temperatures may be more resistant to digestion, thus decreasing the chances that bacteria will be dislodged and transmitted during the early-phase period. However, if components of the host blood meal act to digest the $Y$. pestis biofilm (e.g., [46]) then over time, the biofilm may begin to break-up, providing aggregates that may be subsequently transmitted or defecated. Larger aggregates may become dislodged when bacterial loads are exceptionally high and interfere with the ability of fleas to digest blood or defecate, causing the high mortality observed at $10^{\circ} \mathrm{C}$. It is also possible that components of the biofilm are directly more toxic to fleas at $10^{\circ} \mathrm{C}[15]$.

\section{General implications for plague transmission}

Although we have demonstrated that the ability of $X$. choepis fleas to transmit $Y$. pestis is not significantly impaired by high temperatures, our overall results suggest that plague outbreaks would be less likely to be maintained at 27 and $30^{\circ} \mathrm{C}$ than at $23^{\circ} \mathrm{C}$. Bacterial loads declined in the fleas held at 27 and $30^{\circ} \mathrm{C}$ and fleas held at $27^{\circ} \mathrm{C}$ experienced higher mortality than fleas at $23^{\circ} \mathrm{C}$. It is unclear if these deficiencies in the fleas at the higher temperatures can help explain the declines in human and animal cases of plague observed during hot weather. It is possible that flea survival is simply compromised during hot, dry weather $[1,18,21,33]$. Fleas expend more energy at higher temperatures [47], and therefore, may be more susceptible to starvation or dehydration under such conditions, such that flea densities and flea-host contact rates are not sufficient to sustain epizootic activity. Flea physiological responses at different temperatures, in addition to the $Y$. pestis responses we've discussed, are also likely to play important roles in the abilities of fleas to maintain or clear $Y$. pestis infections. Moreover, the fed status of the flea and the source of blood meal are other factors that may contribute to the energy demands and survival of fleas, as well as the maintenance of $Y$. pestis infections [46-48]. To better understand plague transmission dynamics, a shift in focus on the effects of temperature on these flea-related factors rather than on blockage in the flea may be warranted given our results and recent modeling efforts that have demonstrated the potential significance of unblocked fleas in driving plague dynamics [49].

\section{Conclusions}

Our results emphasize the conclusions that have been made by previous investigators that flea-borne transmission of plague relates to several factors that have been described in the context of the vectorial capacity model: the likelihood of fleas becoming infectious, the ability of fleas to transmit infections once infectious, and the longevity of fleas once infectious [41,50-52]. Another factor that is likely important is the ability of fleas to retain infections $[37,46]$. We have shown here that temperature has the potential to modify all of these factors, but that high temperatures alone do not appear to significantly impair the ability of fleas to transmit $Y$. pestis infections. Our work does, however, question how we define an infectious flea.

In their seminal work, Bacot and Martin [9] described flea infectiousness as it related to the formation of proventricular blockage by $Y$. pestis. Their flea blockage model, subsequently, came to dominate the transmission experiments that followed, even though these authors stressed that partially blocked fleas might also be efficient transmitters and would survive longer than blocked fleas and, thus, would have more opportunities to transmit plague to their rodent hosts [53]. In recent years, evidence has accumulated that supports the concept that partially blocked or unblocked fleas are capable of efficiently transmitting $Y$. pestis under certain conditions. In particular, the demonstration that fleas may become infectious within 24 hours or less following ingestion of an infected blood meal in the early-phase transmission studies by Eisen and others $[25,26,35,36,54]$ strongly challenges the assumption that blocked fleas are necessary for efficient transmission. Observing efficient transmission of $Y$. pestis by fleas maintained at $30^{\circ} \mathrm{C}$, a temperature in which blockage is not expected $[15,24]$, in the current study raises additional questions regarding the requirement for blockage. The mechanism by which unblocked fleas transmit infections is unclear, but may involve a similar process to that described for blocked fleas in that bacteria get dislodged from a bacterial mass and injected into a host with regurgitated blood; whether this process is more likely if the bacteria have colonized the proventriculus, 
and how temperature may influence this colonization, remains unanswered.

In conclusion, our results suggest that what defines a flea as an efficient transmitter of plague should be reexamined and that the regulation of biofilm production in the flea under varying environmental conditions should be further studied to understand how transmission efficiency depends on this process. Such studies would improve our ability to adequately assess and make predictions regarding the effects of climate change on $Y$. pestis' life cycle and transmission dynamics.

\section{Methods}

\section{Infection of fleas}

Methods for infecting fleas, confirming transmission of $Y$. pestis from fleas to naïve, 6-wk-old female Swiss Webster (SW) or SW/CD-1 hybrid outbred mice, quantifying bacterial loads in fleas, and evaluating vector competency were similar to those described by Eisen et al. [25] and Schotthoefer et al. [26]. Briefly, male and female adult fleas of mixed ages were randomly removed from an established colony of $X$. cheopis and starved for 4-7 days at $23^{\circ} \mathrm{C}$. Twenty-four hours prior to being offered an infectious blood meal, fleas were randomly assigned to one of the four temperature treatment groups: $10,23,27$, or $30^{\circ} \mathrm{C}$, placed in glass bell jars in which the relative humidity was maintained around $85 \%$ with a saturated potassium chloride solution [55], and put into incubators (Model 3960 Forma Environmental Chamber, Thermo Scientific, Asheville, NC) set at the corresponding temperatures.

An artificial feeding system, previously described [25] and the fully virulent $Y$. pestis strain, CO963188 $[25,26,35,36,54]$ were used in the current study to infect fleas. On day 0 , fleas were removed from incubators and placed in artificial feeders containing on average $( \pm 1 \mathrm{~s}$. d.) $1.69 \times 10^{9}\left( \pm 1.729 \times 10^{9}\right)$ colony-forming units $(\mathrm{cfu}) / \mathrm{ml}$ of $Y$. pestis CO9631880 in defibrinated Sprague-Dawley rat blood pre-warmed to $37^{\circ} \mathrm{C}$. After $1 \mathrm{hr}$, fleas were removed from feeders and examined using light microscopy. Fleas that had red blood in their guts were identified as having fed and were considered infected and were placed back into incubators and maintained at their respective treatment temperatures; any fleas that did not take a potentially infectious blood meal were discarded.

\section{Flea-borne transmission to naïve mice}

To assess the transmission efficiency of fleas held at different temperatures in the late phase period, groups of 10 fleas each were removed from incubators and placed on anesthetized naïve mice at room temperature for 1 hr. At the three higher temperatures: $23,27,30^{\circ} \mathrm{C}$, transmission efficiency was assessed on days $7,10,14$, 17, 21, and 28 post-infection (p.i.), but because of poor flea survival at $10^{\circ} \mathrm{C}$, we were only able to test the efficiency at this temperature on days 7,10 , and 14 p.i. Following exposure to the naïve mice, the fed status and sex of each flea used in the challenges were determined, and they were placed individually in microcentrifuge tubes and stored at $-70^{\circ} \mathrm{C}$. The remaining surviving fleas not used for a given time point challenge were offered maintenance blood meals on naïve mice at room temperature for $1 \mathrm{hr}$, beginning on day 3 p.i. and every 3-4 days thereafter until the final time point, and then returned to the incubators. This was done to help promote survival of the fleas.

Mice used in the challenge feeds were subsequently held in separate filter-top cages, observed daily, and euthanized at the onset of symptoms considered indicative of $Y$. pestis-induced illness (e.g., slow response to stimuli, ruffled fur). Successful transmission was confirmed in these ill mice by $Y$. pestis anti-F1 antigen direct fluorescent antibody assays (DFA) of liver and spleen smears. Mice that did not display plague symptoms were euthanized on day 21 p.i., and the serum collected from their blood was tested for evidence of resolved infections using passive hemagglutination and inhibition tests (PHA/HI) for antibodies to Y. pestis F1 antigen [56]. A total of 1408 fleas from 12 artificial feeding events were used to obtain a minimum of 4 replicates (= challenged mice) for each temperature and time point. No detectable differences in transmission patterns were observed between SW and SW/CD-1 outbred mice or the fleas used from different artificial feeds (data not shown).

We did not attempt to quantify the proportion of blocked fleas in our study because we felt our attempts to determine the blockage status of fleas using microscopic examinations were too subjective. Moreover, blocked fleas have been observed to become unblocked during a feeding event $[34,40,57]$, and partial blockages, which have been speculated to be as important in transmission as complete blockages [53], would be difficult if not impossible to detect microscopically. Therefore, we were unable to determine if blocked fleas were associated with the transmission events we observed. However, we recorded the presence of fleas that appeared to be clearly blocked (e.g., presence of fresh blood only in or anterior to the proventriculus) infrequently during our study $(<3 \%)$, such that we believe the majority of the fleas used in our study were probably unblocked fleas.

All animal procedures in our experiments were approved by the Division of Vector-Borne Infectious Diseases (Centers for Disease Control and Prevention) Institutional Animal Care and Use Committee. 


\section{Survival of fleas}

For each time point, counts of total live and dead fleas at each temperature were recorded. The surviving fleas not used in the challenge feeds, were offered a maintenance meal on naïve mice and returned to incubators as described above. More than 17,800 fleas were infected in 12 separate artificial feeding events in our experiment. All of these fleas were included in evaluating the effects of temperature and time on flea survival in our analyses.

\section{Estimation of flea infection prevalences and bacterial loads}

The infection status and bacterial loads in the fed fleas used in challenge feedings were determined by grinding fleas in heart infusion broth (HIB) supplemented with $10 \%$ glycerol and performing serial dilutions of flea triturate, plated in duplicate on 6\% sheep blood agar plates. In some cases $(n=137)$, the flea triturate became contaminated with other bacteria, prohibiting accurate $Y$. pestis colony counts. In these cases, flea triturate dilutions were plated on selective Yersinia agar: CefsulodinIrgasan-Novobiocin base/HIB (CIN/HIB) agar. Colony counts of uncontaminated test samples on the CIN/HIB and sheep blood agar were of the same log, and therefore, colony counts for contaminated samples on CIN/ HIB were not adjusted prior to analysis.

\section{Statistical analyses and estimation of per flea transmission efficiencies}

Because we were primarily interested in the effects of warm temperatures on transmission and $Y$. pestis in vivo growth dynamics in fleas, and because we were only able to examine the effect of $10^{\circ} \mathrm{C}$ through day 14 p.i., we focused our temporal data analyses on comparisons among the three higher temperatures: 23,27 , and $30^{\circ} \mathrm{C}$; therefore, unless otherwise indicated all tests discussed below excluded data from the $10^{\circ} \mathrm{C}$ treatment.

Transmission efficiencies per individual flea were estimated for each time point at each of the four temperature treatments, using maximum likelihood estimates calculated in the Microsoft Excel Add-In PooledInfRate, version 3.0 [58]. These estimates are based on the number of infected fleas that fed on an individual mouse and whether or not transmission was observed in that mouse.

The proportions of fleas surviving between time points were compared across temperatures and time points using quasibinomial regression analyses to adjust for the high degree of overdispersion in the proportion data. We examined the effects of temperature and days p.i. on the $\log _{10}$-transformed bacterial counts in fed fleas using a Poisson generalized linear model. Contingency table analyses were used to compare the proportions of fleas that successfully fed on naïve mice at each temperature and days p.i. and the effect of flea sex on feeding success across temperatures and days p.i. Contingency tables were also used to examine the effect of temperature on infection prevalences across days p.i.

We conducted a stepwise logistic regression analysis to identify the significant factors associated with the probability of $Y$. pestis transmission in our experiment. The explanatory variables considered in this analysis were temperature, time point, and variables that related to the characteristics of the flea group that fed on the mice, namely, the proportion of fed, infected fleas, the proportion of fed, infected female fleas, the summed bacterial loads of fed fleas, and the presence or absence of at least one fed flea harboring a minimum of $10^{6}$ bacteria. The latter variable was considered because Hinnebusch et al. [59] and Engelthaler et al. [27] reported evidence that a bacterial load of at least $10^{6}$ in a flea was required for blockage and transmission by $X$. cheopis.

\section{Effects of $\mathrm{Y}$. pestis infection on flea survival at $10^{\circ} \mathrm{C}$}

To determine if the poor survival of fleas at $10^{\circ} \mathrm{C}$ was associated with the low temperature or infection by $Y$. pestis, a separate experiment was conducted in which fleas were assigned to an infected or non-infected treatment group, and thus were offered either a blood meal containing or not containing $Y$. pestis, respectively, during the artificial feed. The fed fleas ( $n=569$ infected and 576 non-infected) from these treatments were then placed in the incubator set at $10^{\circ} \mathrm{C}$ and monitored for survival on days $3,7,10$, and 14 . Any surviving fleas on these days were offered a maintenance blood meal on naïve Swiss Webster mice at room temperature as was done in our temperature experiment. The proportion of fleas surviving between time points was compared between the infected and uninfected groups using a quasibinomial regression analysis.

\section{Acknowledgements}

We thank the Diagnostic and Reference Activity, Bacterial Diseases Branch, Centers for Disease Control and Prevention for supplying reagents used in the DFA and PHA/HI tests. We also thank 3 anonymous reviewers for their helpful comments.

\section{Author details}

${ }^{1}$ Bacterial Diseases Branch, Division of Vector Borne Diseases, National Center for Emerging and Zoonotic, Infectious Diseases, Centers for Disease Control and Prevention, Fort Collins, CO 80521, USA. ${ }^{2}$ Marshfield Clinic Research Foundation, 1000 North Oak Avenue, Marshfield, WI 54449, USA. ${ }^{3}$ Minnesota Department of Health, P. O. Box 64975, St Paul, MN 55164, USA. ${ }^{4}$ Lawrence Livermore National Laboratory, 7000 East Avenue. L-174, Livermore, CA 94550, USA.

\section{Authors' contributions}

AMS, RJE, KLG conceived and designed experiments; AMS, SWB, JLH, SMV, JAM, SKW, CBG, MEW performed experiments; AMS conducted data analysis; 
AMS, RJE, KLG, SWB interpreted results; AMS wrote paper. All authors read and approved the final manuscript

\section{Competing interests}

The authors declare that they have no competing interests.

Received: 28 April 2011 Accepted: 29 September 2011 Published: 29 September 2011

\section{References}

1. Bacot AW, Martin CJ: The respective influences of temperature and moisture upon the survival of the rat flea (Xenopsylla cheopis) away from its host. J Hyg 1924, 23:98-105

2. Silverman J, Rust MK, Reierson DA: Influence of temperature and humidity on survival and development of the cat flea, Ctenocephalides felis (Siphonaptera: Pulicidae). J Med Entomol 1981, 18:78-83.

3. Lindsay LR, Galloway TD: Seasonal activity and temporal separation of four species of fleas (Insecta: Siphonaptera) infesting Richardson's ground squirrels, Spermophilus richardsonii (Rodentia: Sciuridae), in Manitoba, Canada. Can J Zool 1997, 75:1310-1322.

4. Gage KL, Burkot TR, Eisen RJ, Hayes EB: Climate and vectorborne diseases. Am J Prev Med 2008, 35:436-450.

5. Lafferty KD: The ecology of climate change and infectious diseases. Ecology 2009, 90:888-900.

6. Gage KL, Kosoy MY: Natural history of plague: perspectives from more than a century of research. Annu Rev Entomol 2005, 50:505-528.

7. Bibikova VA: Contemporary views on the interrelationships between fleas and the pathogens of human and animal diseases. Ann Rev of Entomology 1977, 22:23-32.

8. Hinnebusch BJ, Erickson DL: Yersinia pestis biofilm in the flea vector and its role in the transmission of plague. Curr Top Microbiol Immunol 2008, 322:229-248

9. Bacot AW, Martin CJ: Observations on the mechanism of the transmission of plague by fleas. J Hyg 1914, 13(Plague Suppl III):423-439

10. Perry RD, Fetherston JD: Yersinia pestis-etiologic agent of plague. Clinical Microbiology Reviews 1997, 10:35-66.

11. Darby C, Hsu JW, Ghori N, Falkow S: Caenorhabditis elegans: plague bacteria biofilm blocks food intake. Nature 2002, 417:243-244.

12. Jarrett CO, Deak E, Isherwood KE, Oyston PC, Fischer ER, Whitney AR, Kobayashi SD, DeLeo FR, Hinnebusch BJ: Transmission of Yersinia pestis from an infectious biofilm in the flea vector. J Infect Dis 2004, 190:783-792

13. Haas GE: Temperature and humidity in the microhabitat of rodent fleas in Hawaiian cane fields. J Med Entomol 1965, 2:313-316.

14. George PV, Webster WJ: Plague inquiry in the Cumbum Valley, south India. Ind J Med Research 1934, 22:77-104.

15. Hinnebusch BJ, Fischer ER, Schwan TG: Evaluation of the role of the Yersinia pestis plasminogen activator and other plasmid-encoded factors in temperature-dependent blockage of the flea. J Infect Dis 1998, 178:1406-1415

16. Perry RD, Bobrov AG, Kirillina O, Jones HA, Pedersen L, Abney J, Fetherston JD: Temperature regulation of the hemin storage $(\mathrm{Hms}+)$ phenotype of Yersinia pestis is posttranscriptional. Journal of Bacteriology 2004, 186:1638-1647

17. Kartman L, Prince FM: Studies on Pasteurella pestis in fleas. V. The experimental plague-vector efficiency of wild rodent fleas compared with Xenopsylla cheopis, together with observations on the influence of temperature. Am J Trop Med Hyg 1956, 5:1058-1070.

18. Kartman L: Effect of differences in ambient temperature upon the fate of Pasteurella pestis in Xenopsylla cheopis. Trans R Soc Trop Med Hyg 1969, 63:71-75.

19. Collinge SK, Johnson WC, Ray C, Matchett R, Grensten J, Cully JF Jr, Gage KL, Kosoy MY, Loye JE, Martin AP: Testing the generality of a trophic-cascade model for plague. Ecohealth 2005, 2:1-11.

20. Pollitzer R: Plague Geneva, Switzerland: World Health Organization; 1954.

21. Cavanaugh DC, Marshall JD Jr: The influence of climate on the seasonal prevalence of plague in the Republic of Vietnam. J Wildl Dis 1972, 8:85-94.

22. Enscore RE, Biggerstaff BJ, Brown TL, Fulgham RF, Reynolds PJ, Engelthaler DM, Levy CE, Parmenter RR, Montenieri JA, Cheek JE, Grinnell RK, Ettestad PJ, Gage KL: Modeling relationships between climate and the frequency of human plague cases in the southwestern United States, 1960-1997. Am J Trop Med Hyg 2002, 66:186-196.

23. Brown HE, Ettestad P, Reynolds PJ, Brown TL, Hatton ES, Holmes JL, Glass GE, Gage KL, Eisen RJ: Climatic predictors of the intra- and interannual distributions of plague cases in New Mexico based on 29 years of animal-based surveillance data. Am J Trop Med Hyg 2010, 82:95-102.

24. Cavanaugh DC: Specific effect of temperature upon transmission of the plague bacillus by the oriental rat flea, Xenopsylla cheopis. Am J Trop Med Hyg 1971, 20:264-273.

25. Eisen RJ, Bearden SW, Wilder AP, Montenieri JA, Antolin MF, Gage KL: Earlyphase transmission of Yersinia pestis by unblocked fleas as a mechanism explaining rapidly spreading plague epizootics. Proc Natl Acad Sci USA 2006, 103:15380-15385.

26. Schotthoefer AM, Bearden SW, Vetter SM, Holmes J, Montenieri JA, Graham CB, Woods ME, Eisen RJ, Gage KL: Effects of temperature on earlyphase transmission of Yersinia pestis by the flea, Xenopsylla cheopis. $J$ Med Entomol 2011, 48:411-417.

27. Engelthaler DM, Hinnebusch BJ, Rittner CM, Gage KL: Quantitative competitive PCR as a technique for exploring flea-Yersina pestis dynamics. Am J Trop Med Hyg 2000, 62:552-560.

28. Lorange EA, Race BL, Sebbane F, Hinnebusch BJ: Poor vector competence of fleas and the evolution of hypervirulence in Yersinia pestis. $J$ Infect Dis 2005, 191:1907-1912

29. Vadyvaloo V, Jarrett C, Sturdevant DE, Sebbane F, Hinnebusch BJ: Transit through the flea vector induces a pretransmission innate immunity resistance phenotype in Yersinia pestis.. PLoS Pathog 2010, 6:e1000783.

30. Brooks RSJ: The influence of saturation deficiency and of temperature on the course of epidemic plague. J Hyg Camb 1917, 15:881-899.

31. Davis DH: Plague in Africa from 1935 to 1949: a survey of wild rodents in African territories. Bull WHO 1953, 9:665-700.

32. Douglas JR, Wheeler CM: Sylvatic plague studies, II. The fate of Pasteurella pests in the flea. J Infect Dis 1943, 72:18-30.

33. Eskey $\mathrm{CR}$, Haas VH: Plague in the western part of the United States. Public Health Bulletin 1940, 254:1-83.

34. Burroughs AL: Sylvatic plague studies: The vector efficiency of nine species of fleas compared with Xenopsylla cheopis. J Hyg 1947, 43:371-396.

35. Eisen RJ, Wilder AP, Bearden SW, Montenieri JA, Gage KL: Early-phase transmission of Yersinia pestis by unblocked Xenopsylla cheopis (Siphonaptera: Pulicidae) is as efficient as transmission by blocked fleas. J Med Entomol 2007, 44:678-682.

36. Wilder AP, Eisen RJ, Bearden SW, Montenieri JA, Tripp DW, Brinkerhoff BJ, Gage KL, Antolin MF: Transmission efficiency of two flea species (Oropsylla tuberculata cynomuris and Oropsylla hirsuta) involved in plague epizootics among prairie dogs. Ecohealth 2008, 5:205-212.

37. Vetter SM, Eisen RJ, Schotthoefer AM, Montenieri JA, Holmes JL, Bobrov AG, Bearden SW, Perry RD, Gage KL: Biofilm formation is not required for early-phase transmission of Yersinia pestis. Microbiology 2010, 156:2216-2225

38. Hinnebusch BJ, Perry RD, Schwan TG: Role of the Yersinia pestis hemin storage (hms) locus in the transmission of plague by fleas. Science 1996 273:367-371

39. Quan SF, Kartman L, McManus AG: Studies on Pasteurella pestis in fleas: II. Experimental blocking of Xenopsylla cheopis with an avirulent strain of $P$. pestis. Science 1954, 120:1101-1102.

40. Wheeler CM, Suyemoto W, Cavanaugh DC: Studies on Pasteurella pestis in various flea species, II. Simplified method for the experimental infection of fleas. J Infect Dis 1956, 98:107-111.

41. Lorange EA, Race BL, Sebbane F, Hinnebusch BJ: Poor vector competence of fleas and the evolution of hypervirulence in Yersinia pestis. $J$ Infect Dis 2005, 191:1907-1912

42. Han Y, Zhou D, Pang X, Zhang L, Song Y, Tong Z, Bao J, Dai E, Wang J, Guo Z, Zhai J, Du Z, Wang X, Huang P, Yang R: DNA microarray analysis of the heat- and cold-shock stimulons in Yersinia pestis. Microbes Infect 2005, 7:335-348

43. Anisimov AP, Dentovskaya SV, Titareva GM, Bakhteeva IV, Shaikhutdinova RZ, Balakhonov SV, Lindner B, Kocharova NA Senchenkova SN, Holst O, Pier GB, Knirel YA: Intraspecies and temperature-dependent variations in susceptibility of Yersinia pestis to the bactericidal action of serum and to polymyxin B. Infect Immun 2005, 73:7324-7331. 
44. Knirel YA, Lindner B, Vinogradov E, Shaikhutdinova RZ, Senchenkova SN, Kocharova NA, Holst O, Pier GB, Anisimov AP: Cold temperature-induced modifications to the composition and structure of the lipopolysaccharide of Yersinia pestis. Carbohydr Res 2005, 340:1625-1630.

45. Knirel YA, Lindner B, Vinogradov EV, Kocharova NA, Senchenkova SN, Shaikhutdinova RZ, Dentovskaya SV, Fursova NK, Bakhteeva IV, Titareva GM, Balakhonov SV, Holst O, Gremyakova TA, Pier GB, Anisimov AP: Temperature-dependent variations and intraspecies diversity of the structure of the lipopolysaccharide of Yersinia pestis. Biochem 2005, 44:1731-1743.

46. Eisen RJ, Vetter SM, Holmes JL, Bearden SW, Montenieri JA, Gage KL: Source of host blood affects prevalence of infection and bacterial loads of Yersinia pestis in fleas. J Med Entomol 2008, 45:933-938.

47. Fielden LJ, Krasnov BR, Khokhlova IS, Arakelyan MS: Respiratory gas exchange in the desert flea Xenopsylla ramesis (Siphonaptera: Pulicidae): response to temperature and blood-feeding. Comp Biochem Physiol A Mol Integr Physiol 2004, 137:557-565.

48. Sarfati M, Krasnov BR, Ghazaryan L, Khokhlova IS, Fielden LJ, Degen AA: Energy costs of blood digestion in a host-specific haematophagous parasite. J Exp Biol 2005, 208:2489-2496.

49. Buhnerkempe MG, Eisen RJ, Goodell B, Gage KL, Antolin MF, Webb CT: Transmission shifts underlie variability in population responses to Yersinia pestis infection. PLoS One 2011, 6:e22498.

50. Eisen RJ, Eisen L, Gage KL: Studies of vector competency and efficiency of North American fleas for Yersinia pestis: state of the field and future research needs. J Med Entomol 2009, 46:737-744.

51. Wheeler CM, Douglas JR: Sylvatic plague studies. V. The determination of vector efficiency. J Infect Dis 1945, 77:1-12.

52. Kartman $L$ : The concept of vector efficiency in experimental studies of plague. Exp Parasitol 1957, 6:599-609.

53. Bacot AW: Further notes on the mechanism of the transmission of plague by fleas. J Hyg 1915, 14(Plague Suppl 4):774-776.

54. Eisen RJ, Holmes JL, Schotthoefer AM, Vetter SM, Montenieri JA, Gage KL: Early-phase transmission of Yersinia pestis by cat fleas (Ctenocephalides felis) and their potential role as vectors in a plague-endemic region of Uganda. Am J Trop Med Hyg 2008, 78:949-956.

55. Winston PW, Bates DH: Saturated solutions for the control of humidity in biological research. Ecology 1960, 41:232-237.

56. Chu MC: Laboratory manual of plague diagnostics Atlanta: Centers for Disease Control and Prevention; 2000

57. Hirst LF: On the transmission of plague by fleas of the genus Xenopsylla. 1922, 789-820.

58. Biggerstaff BJ: PooledlnfRate, Version 3.0: a Microsoft Excel Add-In to compute prevalence estimates from pooled samples Fort Collins: Centers for Disease Control and Prevention; 2006.

59. Hinnebusch BJ, Gage KL, Schwan TG: Estimation of vector infectivity rates for plague by means of a standard curve-based competitive polymerase chain reaction method to quantify Yersinia pestis in fleas. Am J Trop Med Hyg 1998, 58:562-569.

doi:10.1186/1756-3305-4-191

Cite this article as: Schotthoefer et al:: Effects of temperature on the transmission of Yersinia Pestis by the flea, Xenopsylla Cheopis, in the late phase period. Parasites \& Vectors 2011 4:191.

\section{Submit your next manuscript to BioMed Central and take full advantage of:}

- Convenient online submission

- Thorough peer review

- No space constraints or color figure charges

- Immediate publication on acceptance

- Inclusion in PubMed, CAS, Scopus and Google Scholar

- Research which is freely available for redistribution

Submit your manuscript at www.biomedcentral.com/submit
Biomed Central 